\title{
Oil Spill Removal from Water by Absorption on Zinc-Doped Cobalt Ferrite Magnetic Nanoparticles
}

\author{
Ibrahim Ali Amara, b,* (D) Zohour Mohamed Alshibania, Mabroukah Alsalheen AbdulQadir \\ (iD), Ihssin Abubaker Abdalsameda, Fatima Ali Altohamia (iD \\ a Department of Chemistry, Faculty of Science, Sebha University, Sebha, Libya \\ ${ }^{b}$ Central Laboratory at Sebha University, Sebha, Libya
}

\section{A R T I C L E I N F O}

Received: 07 May 2019

Revised: 24 May 2019

Accepted: 06 June 2019

Available online: 06 June 2019

DOI: $10.33945 /$ SAMI/AJCA.2019.4.9

\section{K E Y W O R D S}

Magnetic nanomaterials

Spinel ferrite nanoparticles

Oil spills

Gravimetric oil removal

\section{A B S T R A C T}

In the present study, $\mathrm{Zn}$-doped cobalt ferrite $\left(\mathrm{CoFe}_{1.9} \mathrm{Zn}_{0.104}\right)$ magnetic nanoparticles were successfully synthesized via sol-gel method. The prepared materials were characterized using X-ray powder diffraction (XRD), Fourier transform infrared spectroscopy (FTIR) and scanning electron microscopy (SEM). The apparent density and magnetic force of $\mathrm{CoFe}_{1.9} \mathrm{Zn}_{0.104}$ nanoparticles were determined. The results revealed that the prepared materials display an adequate density and considerable magnetic force. The gravimetric oil removal capability tests were also performed to investigate the oil absorption properties of $\mathrm{CoFe}_{1.9} \mathrm{Zn}_{0.104}$ nanoparticles using four types of oil samples (crude, diesel, gasoline and hydraulic oil) as water pollutant's model. The oil removal capabilities of the prepared absorbent were found to be $13.72 \pm$ $0.42-5.50 \pm 0.53 \mathrm{~g} / \mathrm{g}, 14.99 \pm 0.95-8.86 \pm 0.42 \mathrm{~g} / \mathrm{g}, 18.23 \pm 1.01-8.06$ $\pm 1.26 \mathrm{~g} / \mathrm{g}$ and $10.58 \pm 0.49-5.24 \pm 0.31 \mathrm{~g} / \mathrm{g}$ for crude, diesel engine, gasoline engine and hydraulic oil, respectively. The results suggest that the prepared magnetic nanoparticles can be used as absorbent materials for removing oil spills from water surface.

G R A P H I C A L A B S T R A C T

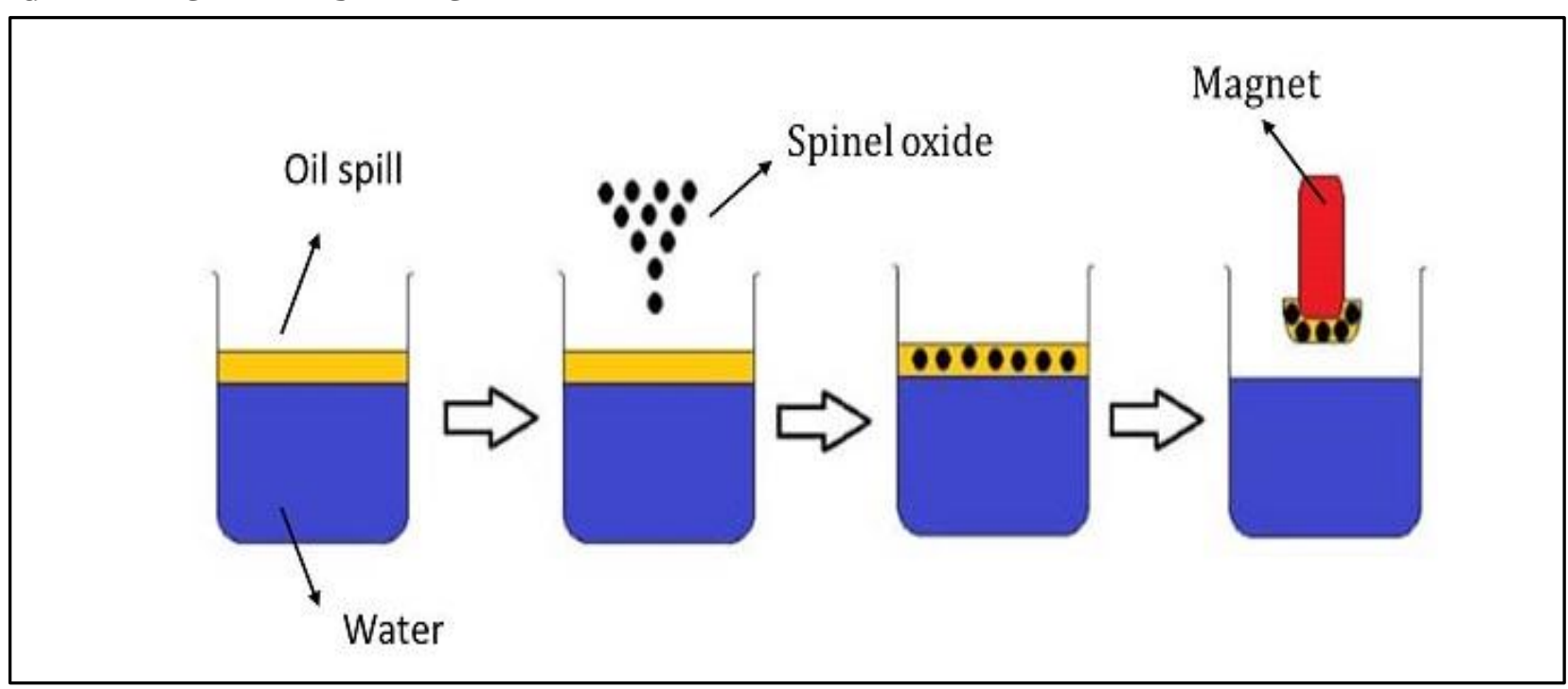

* Corresponding author's E-mail address: ibr.amar@sebhau.edu.ly 


\section{Introduction}

Petroleum and its products play an important role in our daily life. However, there is a great concern regarding oil spills or leakages accidents into water (e.g., sea, ocean, etc.) ) that occur during the extraction, transportation, manipulation and storage of the crude oil $[1,2]$. Globally, the amount of spilt oil is estimated to be approximately 400.000 tons per year [3]. For example, in 2010, an oil spillage occurred in the Deep-water of Gulf of Mexico released an estimated amount of crude oil equals to 4.9 million barrels [4]. Unfortunately, oil spill accidents can pose a potential threat to public health and ecosystem which can lead to huge environmental and economic losses [2,5]. Therefore, it is of crucial importance to develop effective, feasible, economic and advanced technologies to clean up the spills of petroleum and its products.

Currently, different techniques have been devolved for oil spillage clean-up including; chemical (e.g., in-situ burning and dispersion) [6,7], physical (e.g., skimmers and absorption) $[5,8]$ and biological methods [9]. Among these, absorption has gained considerable attention due to its fascinating advantages such as; ease of operation, environmental-friendliness and costeffectiveness, high efficiency, the availability of various absorbent materials and low energy consumption, etc. [10,11]. In this regard, different materials have been used for oil spill clean-up including; inorganic, natural organic and synthetic organic absorbents [12].

Nanotechnology, the developing science, is expected to play an important role in advancing the current technologies for water treatment and also providing secure and sustainable water supplies [13]. Although nanotechnology is still in the stage of research and development for oil spillage treatment, it is holds great promise to provide an effective solution to the problem [1, 14]. In recent years, spinel ferrites (SFs) and their composites (SFCs), the magnetic nanoparticles (MNPs, have attracted great attention owing to their properties such as; ease of preparation and functionalization, diverse structures, cost-effectiveness, high specific surface area, good biocompatibility, moderate saturation magnetization, ease of separation using an external magnetic field, ease of recovery and regeneration and high stabilities (i.e., chemical, mechanical and thermal), etc. [1518]. These properties make them among the materials of first choice for applications in many fields including; ammonia synthesis [19,20], photocatalysis [21], magnetic devices [22], adsorption [23-25], biomedicine [26] and sensors [27], etc. However, few reports have been found in the literature on using spinel ferrite based materials as oil spill absorbents $[2$, 28-30]. Therefore, the main focus of the present work is to investigate the oil removal capability of $\mathrm{Zn}$-doped cobalt ferrite $\left(\mathrm{CoFe}_{1.9} \mathrm{Zn}_{0.104}\right)$ magnetic nanoparticles.

\section{Experimental}

\section{Materials and chemicals}

Crude oil was collected from El-Feel oil field, Awbari, Libya. Diesel, gasoline and hydraulic oils were purchased from local suppliers. The main characteristics (density and viscosity) of the tested oils are listed in Table 1. Iron nitrate $\left(\mathrm{Fe}\left(\mathrm{NO}_{3}\right)_{3} \cdot 9 \mathrm{H}_{2} \mathrm{O}\right)$ was purchased from Berck and Scientific Supplies. Zinc nitrate $\left(\mathrm{Zn}\left(\mathrm{NO}_{3}\right)_{2} \cdot 3 \mathrm{H}_{2} \mathrm{O}\right)$ was supplied by Cosmic Chemicals. Cobalt nitrate $\left(\mathrm{Co}\left(\mathrm{NO}_{3}\right)_{2} \cdot 6 \mathrm{H}_{2} \mathrm{O}\right)$ was purchased from analyticals. Ethylenediaminetetraacetic acid, EDTA, $\left(\mathrm{C}_{10} \mathrm{H}_{18} \mathrm{~N}_{2} \mathrm{O}_{8}\right)$ was purchased from Serva. Citric acid $\left(\mathrm{C}_{6} \mathrm{H}_{8} \mathrm{O}_{7}\right)$ was purchased from Labkem. Ammonia solution (35\%) was purchased from Scharlau.

\section{Synthesis of $\mathrm{CoFe}_{1.9} \mathrm{Zn}_{0.1} \mathrm{O}_{4} \quad$ magnetic nanoparticles}

Combined EDTA-citrate complexing sol-gel process was used to prepare $\mathrm{CoFe}_{1.9} \mathrm{Zn}_{0.1} \mathrm{O}_{4}$ magnetic nanoparticles (CFZ MNPs), as 
described elsewhere [31].

Table 1. The characteristics of the tested oil at $25^{\circ} \mathrm{C}$

\begin{tabular}{ccc} 
Tested oil & $\begin{array}{c}\text { Viscosity } \\
(\mathrm{mPa})\end{array}$ & $\begin{array}{c}\text { Density } \\
\left(\mathrm{g} / \mathrm{cm}^{3}\right)\end{array}$ \\
Crude & 34.3 & 0.8531 \\
Diesel & 32.2 & 0.9005 \\
Gasoline & 35.8 & 0.8913 \\
Hydraulic & 229.8 & 0.8572 \\
\hline
\end{tabular}

Figure 1. A schematic representation of sol-gel process used for the synthesis of $\mathrm{CoFe}_{1.9} \mathrm{Zn}_{0.1} \mathrm{O}_{4}$ absorbent

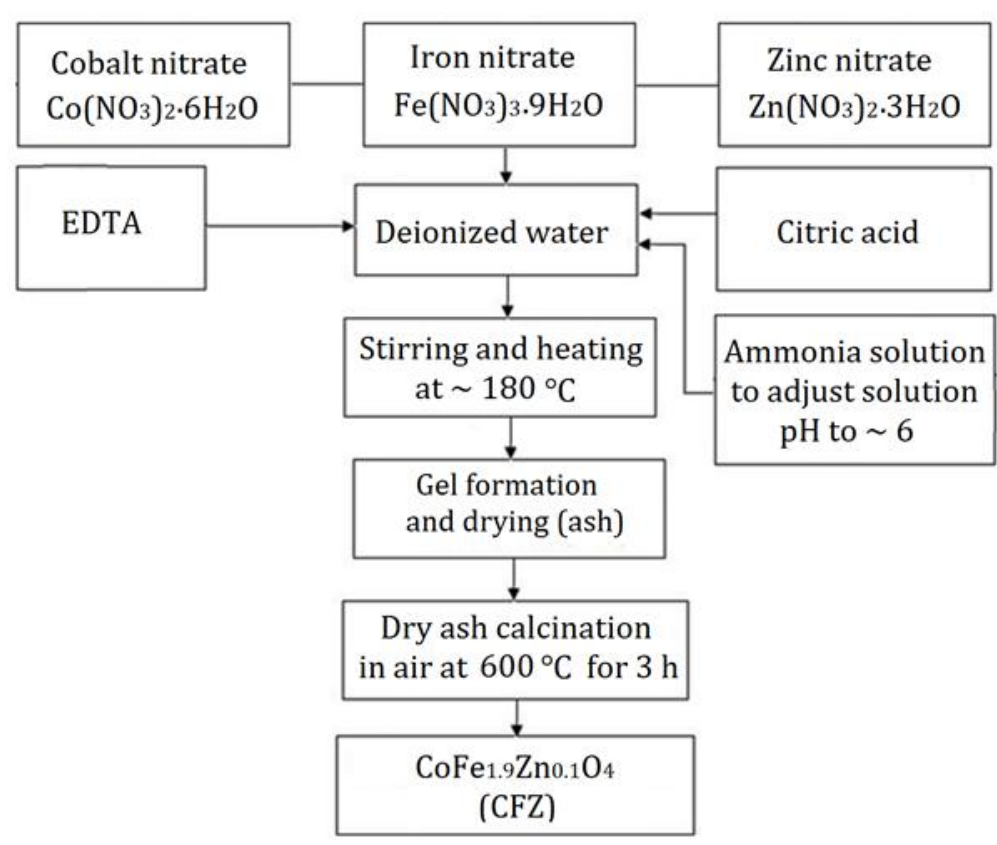

To prepare $10 \mathrm{~g}$ of CFZ MNPs, the required amounts of the starting materials $\left(\left(\mathrm{Fe}\left(\mathrm{NO}_{3}\right)_{3} \cdot 9 \mathrm{H}_{2} \mathrm{O}, 32.5462 \mathrm{~g}\right),\left(\mathrm{Co}\left(\mathrm{NO}_{3}\right)_{2} \cdot 6 \mathrm{H}_{2} \mathrm{O}\right.\right.$, $12.3400 \mathrm{~g})$ and $\left(\mathrm{Zn}\left(\mathrm{NO}_{3}\right)_{2} .3 \mathrm{H}_{2} \mathrm{O}, 1.0321 \mathrm{~g}\right)$ ) were dissolved in deionized water. Then, complexing agents of EDTA (37.1805 g) and citric acid (40.0947 g) were added to the solution of metal nitrates with a ratio of metal cations: EDTA: citric acid of 1:1:1.5. Afterwards, the $\mathrm{pH}$ of that mixed solution was adjusted to around 6 using a diluted ammonia solution. Then, the mixture was evaporated under heating and stirring to dryness to get a solid product (ash). Finally, ultrafine black powder of CFZ MNPs was obtained after firing the ash in air at $600{ }^{\circ} \mathrm{C}$ for $3 \mathrm{~h}$. Figure 1 is a flowchart representing the overall sol-gel process used for CFZ MNPs synthesis.

\section{Characterization}

The X-ray diffraction (XRD) pattern of $\mathrm{CoFe}_{1.9} \mathrm{Zn}_{0.1} \mathrm{O}_{4}$ magnetic nanoparticles (CFZ MNPs) was recorded at room temperature using a Philips - PW 1800 diffractometer with $\mathrm{CuK} \alpha$ radiation $(\lambda=1.54186 \AA)$. The crystallite size $(D)$, lattice parameters $(a)$, unit cell volume $\left(V_{\text {cell }}\right)$, the X-ray density $\left(\rho_{X R D}\right)$ and the specific surface area $\left(S_{X R D}\right)$ of CFZ MNPs were estimated using the 
following Equations [32,33];

$$
\begin{aligned}
& D=\frac{0.9 \lambda}{(\beta \cos \theta)} \\
& a=d_{h k l} \sqrt{h^{2}+k^{2}+l^{2}} \\
& V_{\text {cell }}=a^{3} \\
& \rho_{X R D}=\frac{Z M}{N_{A} V_{c e l l}} \\
& S_{X R D}=\frac{6000}{D \cdot \rho_{X R D}}
\end{aligned}
$$

Where $\lambda$ is the wavelength of the $\mathrm{X}$-ray, $\theta$ is the Bragg angle, $\beta$ is the full width at half maximum (FWHM) of the peak in radiance, $d$ is the interplanar distance, $h k l$ are the Miller indices, $M$ is the molecular weight of the sample, $\mathrm{Z}$ is the number of molecules per formula unit ( $\mathrm{Z}=8$ for spinel system) and $N_{A}$ is the Avogadro's number.

The Fourier transform infrared (FTIR) analysis of the prepared absorbent (CFZ MNPs) was carried out using the $\mathrm{KBr}$ disc method with Nicolet 380 spectrometer in the wavenumber range of $400-4000 \mathrm{~cm}^{-1}$. The FTIR spectra of oil sample were recorded in attenuated total reflectance mode (ATR) using a Bruker Tensor 27 spectrometer in the range of 400-4000 $\mathrm{cm}^{-1}$. The surface morphology of CFZ MNPs was investigated using a LEO 1430PV scanning electron microscope (SEM).

The apparent density of CFZ MNPs was measured by determining their weight and volume inside a $5 \mathrm{~mL}$ graduated cylinder [34]. Then, the apparent density was estimated using the following equation [35];

$$
\rho_{\mathrm{a}}\left(\mathrm{g} / \mathrm{cm}^{3}\right)=\frac{W_{s}}{V_{s}}
$$

Where $\rho_{\mathrm{a}}$ is the apparent density, $W$ and $V$ are the absorbent weight and volume inside the graduated cylinder, respectively.

The magnetic force test of CFZ MNPs was performed using a balance (Triple beam, 700/800 Series, OHAUS ${ }^{\circledR}$ ), electromagnet, power supply (Hochstrom-Netzerat, LEYBOLD) and Teslameter (LEYBOLD, DIDACTIC GMBH). The CFZ MNPs sample was subjected to a magnetic field which was produced by an electromagnetic. An electric current ranging from 0.00 to $0.9 \mathrm{~A}$ was applied to increase the magnetic field intensity. Finally, the magnetic force was estimated using the following equation [36];

$$
F_{m}=\Delta m \times g
$$

Where $F_{m}$ is the magnetic force, $g$ and $\Delta m$ are the acceleration of gravity and the apparent variation of mass in the presence of the magnetic field.

\section{Oil removal experiments}

The oil removal tests were performed as described previously in the literature [3638]. In this test, $20 \mathrm{~mL}$ of deionized water was poured into a $25 \mathrm{~mL}$ beaker and a certain amount of the tested oil $(0.2 \mathrm{~g}, 0.5$ $\mathrm{g}, 0.5 \mathrm{~g}$ and $0.3 \mathrm{~g}$ for crude, gasoline, diesel and hydraulic oil, respectively) was split on the top of water surface. Afterwards, a known mass (0.01-0.04 g) of the CFZ MNPs was added onto the tested oil spot. After that, the beaker was left for 5 min before the CFZ MNPs and the oil spill being removed magnetically with the help of a permanent magnet. The triplicated oil removal tests were conducted at room temperature. Finally, the gravimetric oil removal was estimated using the following equation;

$$
O R=\frac{m_{2}-m_{3}}{m_{1}}
$$

Where $O R$ is oil removal $(\mathrm{g} / \mathrm{g}), m_{1}$ is the weight of CFZ MNPs, $m_{2}$ is the total weight 
of the beaker (containing the water, oil spot and CFZ MNPs) and $m_{3}$ is the weight of the beaker (weight of oil residue) after removing CFZ MNPs that absorb the tested oil.

\section{Results and discussion}

\section{Characterizations}

Figure 2 shows the X-ray diffraction (XRD) pattern of CFZ MNPs which obtained after the calcination of its corresponding gel precursor in air at $600{ }^{\circ} \mathrm{C}$ for $3 \mathrm{~h}$. As can be seen, the observed diffraction peaks were well indexed to the crystalline planes of cobalt ferrite $\left(\mathrm{CoFe}_{2} \mathrm{O}_{4}\right)$ with a cubic structure (JCPDS card No. 22-1086). In addition, no peaks were observed in the XRD pattern apart from those corresponding to CFZ MNPs. This confirms that a single phase of $\mathrm{CoFe}_{1.9} \mathrm{Zn}_{0.1} \mathrm{O}_{4}$ MNPs was successfully synthesized. The XRD data corresponding to the (311) crystal plane was used to estimate the values of the structural parameters of CFZ MNPs including the crystallite size $(D)$, lattice constant $(a)$, unit cell volume $\left(V_{\text {cell }}\right)$, the $\mathrm{X}$ ray density $\left(\rho_{X R D}\right)$ and the specific surface area $\left(S_{X R D}\right)$. The calculated values of $D, a$, $V_{\text {cell }}, \rho_{X R D}, S_{X R D}$ and were found to be 21.22 $\mathrm{nm}, 8.3451 \AA, 581.15 \AA^{3}, 5.38 \mathrm{~g} / \mathrm{cm}^{3}$ and
$52.56 \mathrm{~m}^{2} / \mathrm{g}$, respectively. In addition, the lattice constant value of CFZ MNPs is comparable to that reported by Kumar et al. [39] for $\mathrm{CoFe}_{2} \mathrm{O}_{4}$ MNPs (8.3783 $\AA$ ) and $\mathrm{CoFe}_{1.9} \mathrm{Zn}_{0.1} \mathrm{O}_{4}$ MNPs (8.3775 ̊̊).

Figure 3 displays the FTIR spectrum of CFZ MNPs within the range of wavenumber from 400 to $4000 \mathrm{~cm}^{-1}$. As shown, the absorption band $\left(v_{1}\right)$ located at $570 \mathrm{~cm}^{-1}$ is assigned to oxygen ion-tetrahedral metal ion $\left(\mathrm{O}-\mathrm{M}_{\mathrm{Tet}}\right)$ bond stretching vibration. This characteristic band indicates the formation of spinel ferrite and it is observed in FTIR spectra of all spinel ferrites [39, 40]. The observed absorption bands within the wavenumber range of $881-1135 \mathrm{~cm}^{-1}$ are accredited to $\mathrm{NO}_{3}^{-}$vibration [41]. The absorption peak at $1496 \mathrm{~cm}^{-1}$ is corresponding to $\mathrm{C}$ - $\mathrm{H}$ bending vibration [42]. The observed peaks at approximately 3456 and $1638 \mathrm{~cm}^{-1}$ were assigned to stretching and bending vibrations of $\mathrm{O}-\mathrm{H}$, respectively [41].

Figure 4 shows the surface morphology of CFZ MNPs which was investigated using scanning electron microscope (SEM). From the SEM image, it is clearly seen that the surface of CFZ MNPs contains large grains which are agglomerated and irregular in shape. These agglomerates are formed due to the interactions between CFZ nanoparticles $[23,43]$.
Figure 2. X-ray diffraction pattern of $\mathrm{CoFe}_{1.9} \mathrm{Zn}_{0.1} \mathrm{O}_{4}$ magnetic nanoparticles

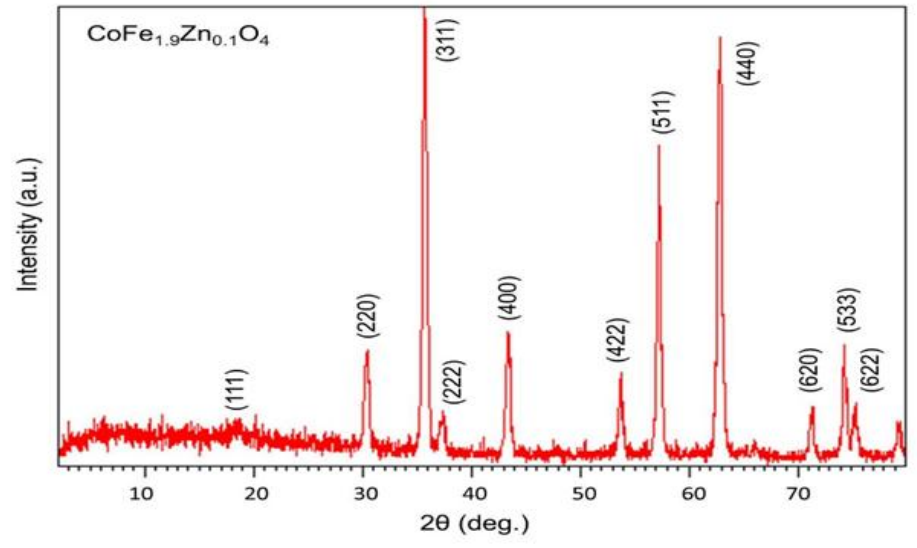


Figure 3. FTIR spectrum of $\mathrm{CoFe}_{1.9} \mathrm{Zn}_{0.1} \mathrm{O}_{4} \quad$ magnetic nanoparticles

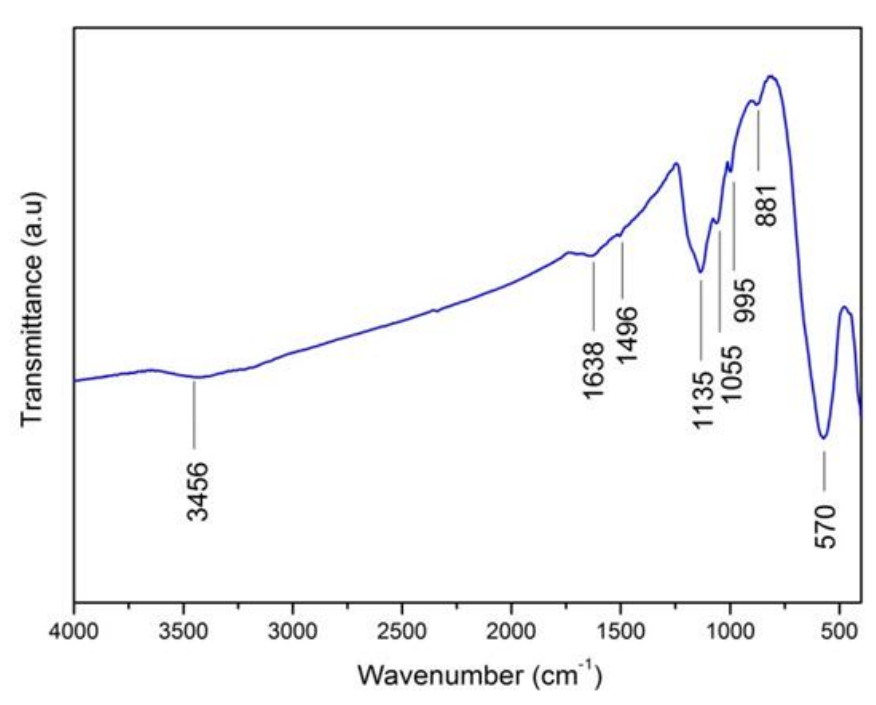

Figure 4. SEM image of $\mathrm{CoFe}_{1.9} \mathrm{Zn}_{0.1} \mathrm{O}_{4}$ magnetic nanoparticles

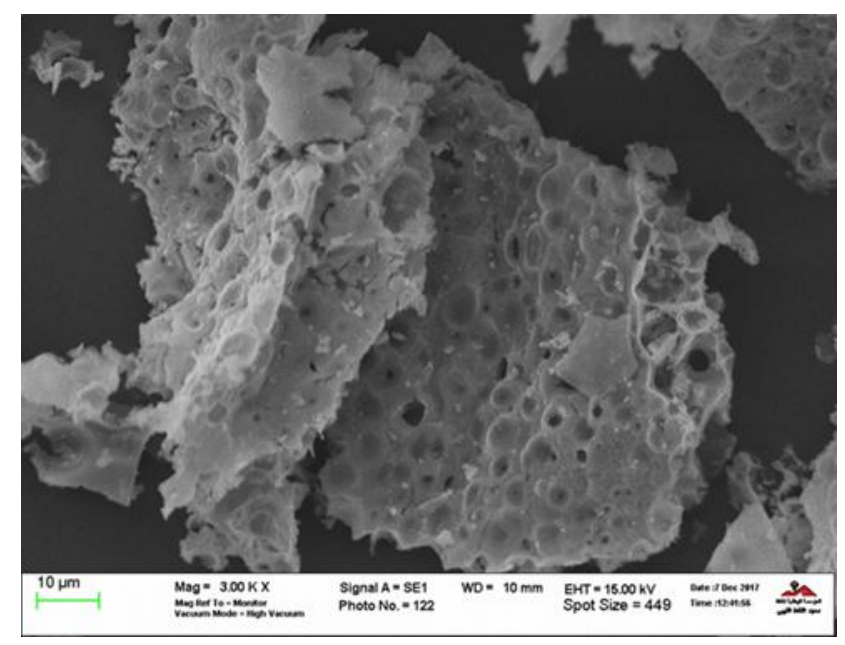

It can be also seen from the SEM image that the observed large grains are surrounded by many pores. This porous structure will provide both, a large contact area between the absorbent surface and oil droplets and also more space for oil preservation [35]. In addition, the apparent density $\left(\rho_{\mathrm{a}}\right)$ of $\mathrm{CFZ}$ MNPs was found to be $0.74 \pm 0.08 \mathrm{~g} / \mathrm{cm}^{3}$. This value is comparable to that of $\mathrm{Fe}_{2} \mathrm{O}_{3} /$ resin magnetic nanocomposite $\left(0.811 \pm 0.002 \mathrm{~g} / \mathrm{cm}^{3}\right)$ which reported by Varela et al. [3]. The obtained density indicates that CFZ MNPs can float easily on the surface of contaminated water and will act as a good material for oil absorption [3, 38]. The magnetic force of CFZ MNPs was around $42.18 \mathrm{mN}$. This value is lower than that of pure maghemite (355 $\mathrm{mN}$ ) and higher than that of maghemite-magnetic nanocomposite $(5.1 \mathrm{mN})$ [36]. The observed magnetic force value suggests that CFZ MNPs can be easily removed after the oil absorption test using an external magnetic field (see Figure 7).

Figure 5 displays the FTIR-ATR spectra of the tested oil materials (crude, diesel, hydraulic and gasoline) within the range of wavenumber from 600 to $4000 \mathrm{~cm}^{-1}$. As can be seen, all tested oils exhibit similar FTIRATR spectra. The absorption band located at $722 \mathrm{~cm}^{-1}$ is resulted from $\mathrm{CH}_{2}$ rocking vibration. The absorption band which 
observed at $1074 \mathrm{~cm}^{-1}$ is accredited to ester linkages present in the asphaltene molecule. The presence of two absorption bands at 1370 and $1463 \mathrm{~cm}^{-1}$ are assigned to $\mathrm{C}-\mathrm{H}$ bending vibration in methyl and methylene, respectively. In addition, the characteristic two absorption bands located at 2863 and $2928 \mathrm{~cm}^{-1}$ are attributed to asymmetric and symmetric stretching vibration for aliphatic C-H groups [44,45].

\section{Gravimetric oil removal}

In this study, four types of oil sample (crude, diesel, gasoline and hydraulic) were used in the oil removal tests. Table 1 lists the characteristics (viscosity and density) of these oil samples. Figure 6 displays the gravimetric oil removal $(O R$, $\mathrm{g} / \mathrm{g}$ ) or the oil absorption capacity of the tested oily samples as a function of absorbent amount. As can be seen, in all cases the gravimetric oil removal decrease with the increase in the amount of the adsorbent from 0.01 to $0.04 \mathrm{~g}$. In the case of crude oil (Figure 6 a), the $O R$ decreased from $13.72 \pm 0.42 \mathrm{~g} / \mathrm{g}$ to $5.50 \pm 0.53 \mathrm{~g} / \mathrm{g}$ as the amount of absorbent (CFZ MNPs) increased from 0.01 to $0.04 \mathrm{~g}$. For the diesel engine oil, the $O R$ was about $14.99 \pm 0.95$ $\mathrm{g} / \mathrm{g}$ at the absorbent amount of $0.01 \mathrm{~g}$ and reached a value of $8.86 \pm 0.42 \mathrm{~g} / \mathrm{g}$ when the absorbent amount increased to $0.04 \mathrm{~g}$ (Figure $6 \mathrm{~b}$ ). For the gasoline engine oil (Figure $6 \mathrm{c}$ ), the $O R$ was about $18.23 \pm 1.01$ $\mathrm{g} / \mathrm{g}$ and decreased to a value of $8.06 \pm 1.26$ $\mathrm{g} / \mathrm{g}$ as the absorbent amount increased to $0.04 \mathrm{~g}$. In the case of hydraulic oil, the $O R$ was $10.58 \pm 0.49 \mathrm{~g} / \mathrm{g}$ when the amount of absorbent was $0.01 \mathrm{~g}$ and decreased to a value of $5.24 \pm 0.31 \mathrm{~g} / \mathrm{g}$ with the increase in absorbent amount to $0.04 \mathrm{~g}$, as shown in Figure $6 \mathrm{~d}$. This decrease in the oil absorption capacity (g/g) with the increase in the absorbent amount was also reported by Ognjanovic et al. [46] for the removal of motor oil from water using organic absorbent materials.
Figure 5. ATR-FTIR spectra of the tested oil samples

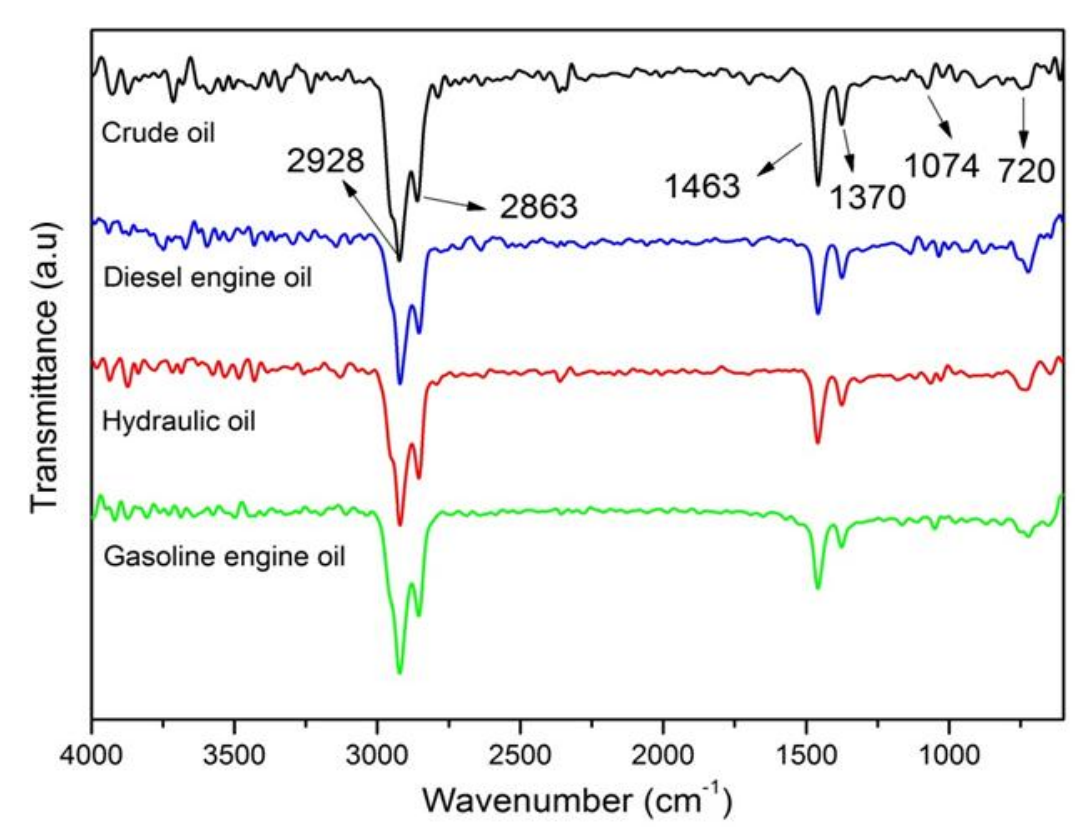

Adv J Chem A 2019, 2(4), 365-376 

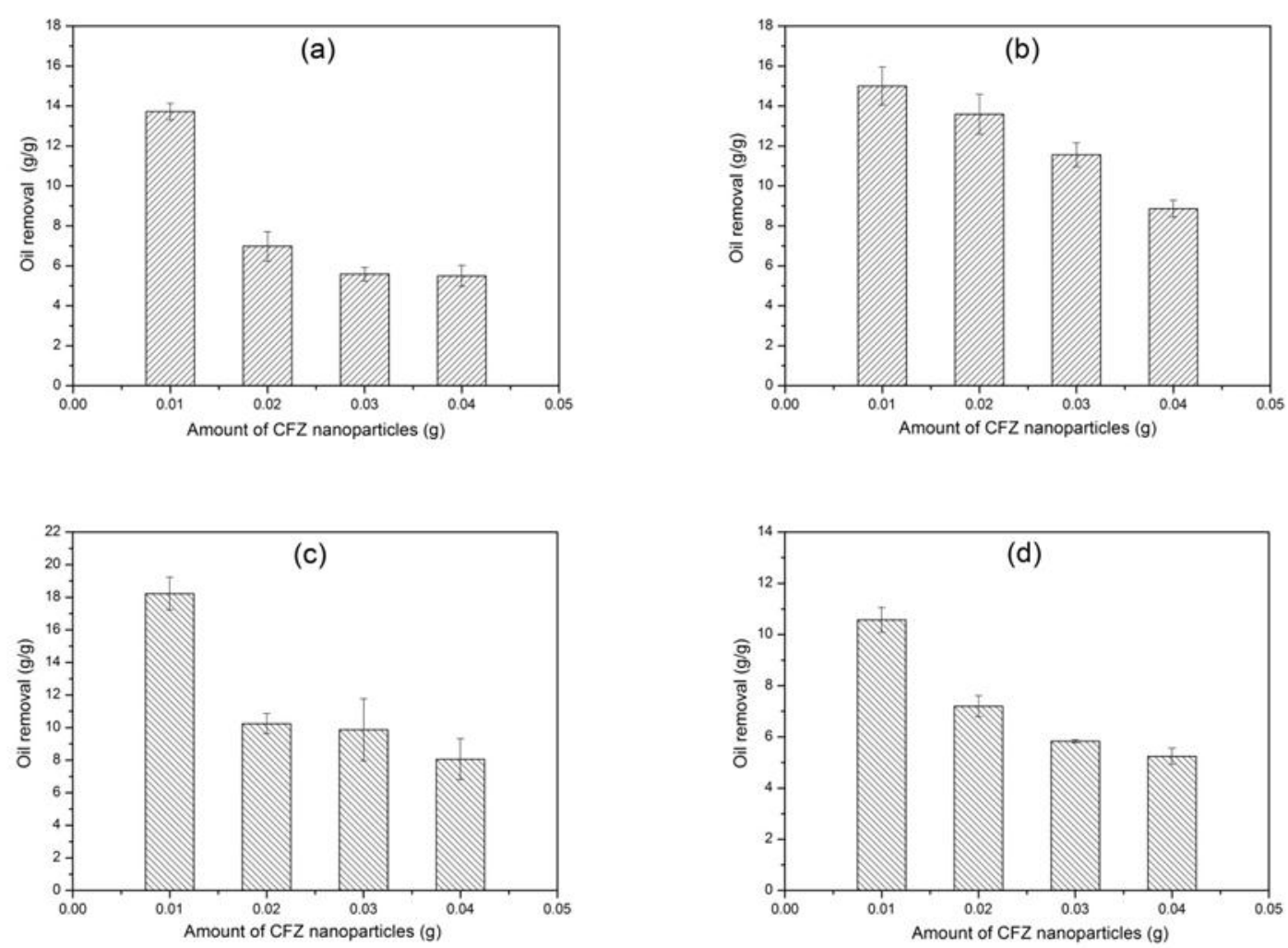

Figure 6. Oil removal as function of absorbent amount, (a) crude oil; (b) diesel oil; (c) gasoline oil; (d) hydraulic oil
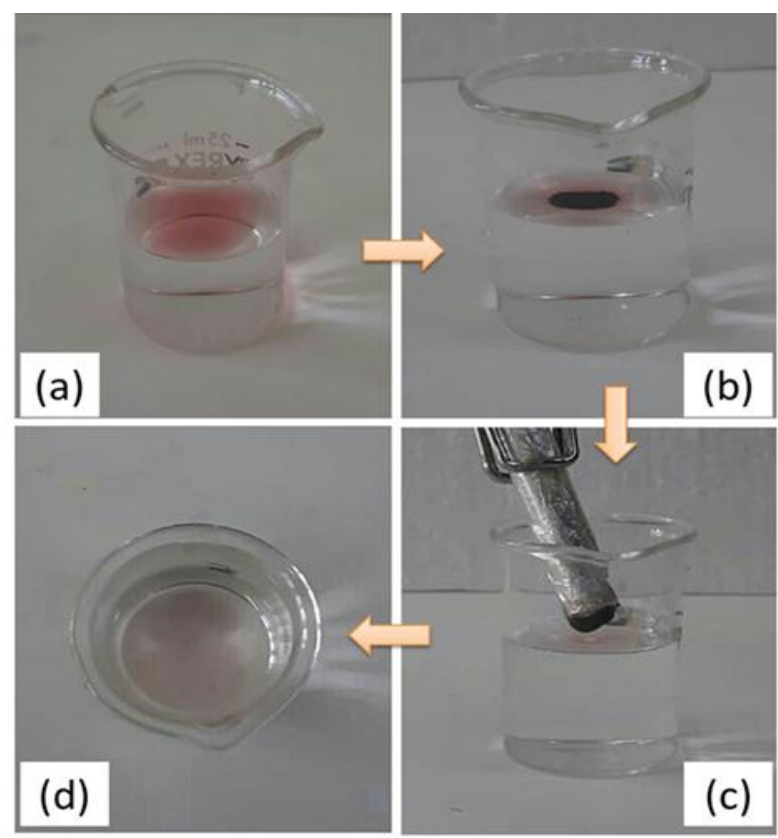

Figure 7. Images showing the removal of hydraulic oil from water surface, (a) hydraulic oil spilt over water surface; (b) CFZ MNPs on the top of hydraulic oil spill; (c) removal of CFZ MNPs loaded with oil by magnetic bar; (d) water surface after separating the CFZ MNPs loaded with hydraulic oil 
This could be due to CFZ MNPs aggregation which in turn will result in reducing the absorbent surface area and also preventing the oil spill from penetrating into the available pores of the absorbent material. In general, the difference in gravimetric oil removal capabilities between the tested oily liquid could be due to many factors including the oil density, viscosity and the affinity of oil towards the absorbent material, etc. Figure 7 represents images showing an example of the gravimetric oil removal test (hydraulic oil). As shown from the image, the CFZ MNPs loaded with the tested can be easily removed from the water surface after the oil removal test.

Figure 8 shows the relationship between the gravimetric oil removal and the density of the tested oil sample at two different absorbent amounts $(0.01 \mathrm{~g}$ and $0.04 \mathrm{~g})$. As shown from the figure, the gravimetric oil removal generally increased with increasing the oil density in both cases. It was observed that the diesel engine and gasoline engine oil which exhibit the highest densities (see Table 1) provided the higher gravimetric oil removal. In this way, at absorbent amount of $0.01 \mathrm{~g}$ (Figure 8 a) gasoline engine oil show the highest gravimetric oil removal $(18.23 \pm 1.01 \mathrm{~g} / \mathrm{g})$. However, when the absorbent amount was $0.04 \mathrm{~g}$ (Figure $8 \mathrm{~b}$ ), the diesel engine oil which has the highest density among other tested oily liquid $\left(0.9005 \mathrm{~g} / \mathrm{cm}^{3}\right)$ exhibits the greater gravimetric oil removal $(8.86 \pm$ $0.42 \mathrm{~g} / \mathrm{g}$ ). This tendency of increasing the gravimetric oil removal capabilities or oil absorption capacity with oil density was observed by other research groups [3, 47]. As stated by Cao et al. [5], the direct comparison of the oil absorption capacities using different absorbent materials is quite difficult. This is acutely because different oil types and absorbent amount were used. In addition, the oil absorption is complicated process and is affected by many factors including; the properties of the absorbent (e.g., surface area, porosity, etc.) and the tested oil (e.g., density and oil viscosity, etc.). Table 2 lists the applications of some magnetic nanomaterials and their composites for the removal of various types of oil samples in comparison with the prepared absorbent (CFZ MNPs) [1, 4, 18, 28, 29, 34, 37, 48, 49]. As can be seen from the table, the value of oil absorption capacity of CFZ MNPs is comparable to those reported previously for other materials. However, the reported oil absorption value for CFZ MNPs was in some cases higher than those observed by others. This indicates that the prepared absorbent (CFZ MNPs) is promising material and can be tested for the removal of other water pollutants.
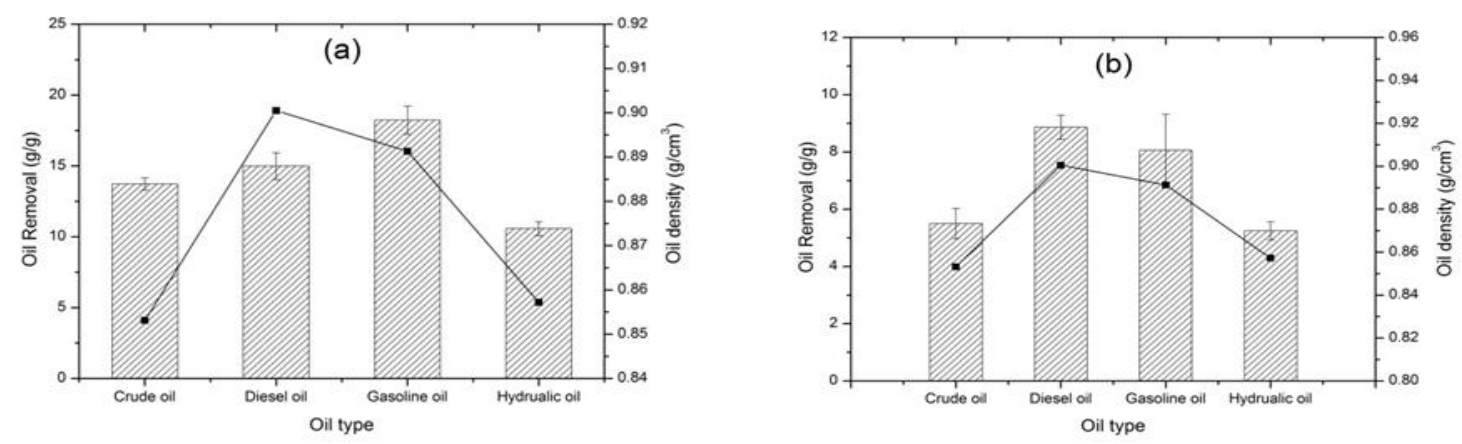

Figure 8. Relationship between the gravimetric oil removal and oil density, (a) absorbent amount of $0.01 \mathrm{~g}$; (b) absorbent amount of $0.04 \mathrm{~g}$ 
Table 2. Comparison of different types of oil absorbing materials

\begin{tabular}{|c|c|c|c|}
\hline Absorbent material & Type of oil & $\begin{array}{l}\text { Oil removal } \\
(\mathrm{g} / \mathrm{g})\end{array}$ & Reference \\
\hline $\mathrm{PBS} / \mathrm{Fe}_{2} \mathrm{O}_{3}$ & Crude oil & 11.06 & [48] \\
\hline$\gamma-\mathrm{Fe}_{2} \mathrm{O}_{3} /$ resin & Crude oil & 8.33 & {$[37]$} \\
\hline $\mathrm{Fe}_{3} \mathrm{O}_{4}$ & Crude oil & 2.16 & {$[18]$} \\
\hline$\gamma-\mathrm{Fe}_{2} \mathrm{O}_{3} / \mathrm{GC}$ & Crude oil & 25.1 & {$[34]$} \\
\hline $\mathrm{PS} / \mathrm{NiFe}_{2} \mathrm{O}_{4}$ & Motor oil & 15.11 & [29] \\
\hline $\mathrm{PVDF} / \mathrm{CoFe}_{2} \mathrm{O}_{4}$ & Motor oil & 18.07 & {$[28]$} \\
\hline $\mathrm{Fe}_{3} \mathrm{O}_{4}$ & Motor oil & 3.52 & {$[18]$} \\
\hline $\mathrm{Fe}_{3} \mathrm{O}_{4} / \mathrm{PS}$ & Diesel oil & 2.49 & {$[4]$} \\
\hline $\mathrm{Fe}_{3} \mathrm{O}_{4} /$ Silica & Diesel oil & 3.78 & {$[1]$} \\
\hline $\mathrm{Fe}_{3} \mathrm{O}_{4} / \mathrm{Tween}$ & Diesel oil & 32 & {$[49]$} \\
\hline $\mathrm{CoFe}_{1.9} \mathrm{Zn}_{0.1} \mathrm{O}_{4}$ & Crude oil & $5.50-13.72$ & This study \\
\hline $\mathrm{CoFe}_{1.9} \mathrm{Zn}_{0.1} \mathrm{O}_{4}$ & Diesel oil & $8.86-14.99$ & This study \\
\hline $\mathrm{CoFe}_{1.9} \mathrm{Zn}_{0.1} \mathrm{O}_{4}$ & Motor oil & $8.06-18.23$ & This study \\
\hline $\mathrm{CoFe}_{1.9} \mathrm{Zn}_{0.1} \mathrm{O}_{4}$ & Hydraulic oil & $5.24-10.58$ & This study \\
\hline
\end{tabular}

GC = Ground Coffee, $\mathrm{PBS}=$ Poly (butylene Succinate), $\mathrm{PS}=$ polysulfone, $\mathrm{PVDF}=$ Polyvinylidene

\section{Conclusion}

In summary, oil absorbent material based on $\mathrm{Zn}$-doped $\mathrm{CoFe}_{2} \mathrm{O}_{4}$ magnetic nanoparticles (CoFe $\left.\mathrm{C}_{1.9} \mathrm{Zn}_{0.1} \mathrm{O}_{4}, \mathrm{CFZ} \mathrm{MNPs}\right)$ was successfully synthesized using sol-gel process. A single phase with a spinel type structure was obtained after firing the as-prepared material in air at $600{ }^{\circ} \mathrm{C}$ for $3 \mathrm{~h}$, as confirmed by X-ray diffraction technique (XRD). Gravimetric oil removal test was conducted to investigate the properties of CFZ MNPs for absorbing oil spills from water surface. Four types of oil samples (crude, diesel engine, gasoline engine and hydraulic) were used as water pollutants model. Within the absorbent amount of 0.01 to $0.04 \mathrm{~g}$, the gravimetric oil removal capabilities were found to be $13.72 \pm 0.42$ $5.50 \pm 0.53 \mathrm{~g} / \mathrm{g}, 14.99 \pm 0.95-8.86 \pm 0.42 \mathrm{~g} / \mathrm{g}$, $18.23 \pm 1.01-8.06 \pm 1.26 \mathrm{~g} / \mathrm{g}$ and $10.58 \pm 0.49-$ $5.24 \pm 0.31 \mathrm{~g} / \mathrm{g}$ for crude, diesel engine, gasoline engine and hydraulic oil samples, respectively. The obtained results suggest that CFZ MNPs might be promising absorbent materials and can be used for oil-spill cleanup from water surface.

\section{Acknowledgement}

The authors would like to thank Department of Chemistry, Sebha University, Sebha, Libya for the financial support of this work. The authors thank Prof. Taher M. Hassan from Department of Chemistry, Sebha University, for supplying the crude oil. The authors also thank the Criminal Investigation Department, Branch Sabha City for FTIR instrument. The authors are grateful to Dr. Ftema Aldbea from Physics department, Sebha University for providing instruments for magnetic force measurement. The authors also thank the Libyan Petroleum Institute, Tripoli, Libya for performing XRD and SEM analysis. 


\section{Conflict of Interest}

We have no conflicts of interest to disclose.

\section{ORCID}

\section{A. Amar (D): 0000-0002-6757-3722 \\ M. A. AbdulQadir (D): 0000-0003-1674-9211 \\ F. A. Altohami (D): 0000-0002-9513-9069}

\section{References}

[1] L. Yu, G. Hao, Q. Liang, S. Zhou, N. Zhang, W. Jiang, Appl. Surf. Sci., 2015, 357, 2297-2305.

[2] P.P. Dorneanu, C. Cojocaru, P. Samoila, N. Olaru, A. Airinei, A. Rotaru, Polym. Adv. Technol., 2018, 29, 1435-1446.

[3] A. Varela, G. Oliveira, F. Souza Jr, C. Rodrigues, M. Costa, Polym. Eng. Sci., 2013, 53, 44-51.

[4] L. Yu, G. Hao, J. Gu, S. Zhou, N. Zhang, W. Jiang, J. Magn. Magn. Mater., 2015, 394, 14-21. [5] E. Cao, W. Xiao, W. Duan, N. Wang, A. Wang, Y. Zheng, Ind. Crop. Prod., 2018, 115, 272-279. [6] Q. Lin, I.A. Mendelssohn, K. Carney, S.M. Miles, N.P. Bryner, W.D. Walton, Environ. Sci. Technol., 2005, 39, 1855-1860.

[7] E.B. Kujawinski, M.C. Kido Soule, D.L. Valentine, A.K. Boysen, K. Longnecker, M.C. Redmond, Environ. Sci. Technol., 2011, 45, 1298-1306.

[8] V. Broje, A.A. Keller, J. Hazard. Mater., 2007, 148, 136-143.

[9] J.R. Bragg, R.C. Prince, E.J. Harner, R.M. Atlas, Nature, 1994, 368, 413-418.

[10] K. Zhu, Y.Y. Shang, P.Z. Sun, Z. Li, X.M. Li, J.Q. Wei, K.L. Wang, D.H. Wu, A.Y. Cao, H.W. Zhu, Front. Mater. Sci., 2013, 7, 170-176.

[11] J. Jiang, Q. Zhang, X. Zhan, F. Chen, ACS Sustain. Chem. Eng., 2017, 5, 10307-10316.

[12] N. Bhardwaj, A.N. Bhaskarwar, Environ. Pollut., 2018, 243, 1758-1771.

[13] Y. Zhang, B. Wu, H. Xu, H. Liu, M. Wang, Y. He, B. Pan, NanoImpact., 2016, 3-4, 22-39.

[14] B.I. Kharisov, H.V.R. Dias, O.V. Kharissova, J. Petrol. Sci. Eng., 2014, 122, 705-718.

[15] K.K. Kefeni, B.B. Mamba, T.A.M. Msagati,
Sep. Purif. Technol., 2017, 188, 399-422.

[16] J. Gomez-Pastora, E. Bringas, I. Ortiz, Chem. Eng. J., 2014, 256, 187-204.

[17] D.H.K. Reddy, Y.S. Yun, Coord. Chem. Rev., 2016, 315, 90-111.

[18] K.B. Debs, D.S. Cardona, H.D.T. da Silva, N.N. Nassar, E.N.V.M. Carrilho, P.S. Haddad, G. Labuto, J. Environ. Manage., 2019, 230, 405412.

[19] I.A. Amar, R. Lan, C.T.G. Petit, V. Arrighi, S. Tao, Solid State Ionics., 2011, 182, 133-138.

[20] I.A. Amar, C.T. Petit, G. Mann, R. Lan, P.J. Skabara, S. Tao, Int. J. Hydrogen Energ., 2014, 39, 4322-4330.

[21] D. Hong, Y. Yamada, M. Sheehan, S. Shikano, C. H. Kuo, M. Tian, C. K. Tsung, S. Fukuzumi, Chen, ACS Sustain. Chem. Eng., 2014, 2, 2588-2594.

[22] Y. Suzuki, Annu. Rev. Mater Res., 2001, 31, 265-289.

[23] S. Farooq, A. Saeed, M. Sharif, J. Hussain, F. Mabood, M. Iftekhar, J. Water Process Eng., 2017, 16, 132-141.

[24] I.A. Amar, A. Sharif, M. Alkhayali, M. Jabji, F. Altohami, M. AbdulQadir, IJEE., 2018, 9, 247-254.

[25] I.A. Amar, A. Sharif, N.A. Omer, N.E. Akale, F. Altohami, M.A. AbdulQadir, Synthesis and Characterization of Magnetic $\mathrm{CoFe}_{1.9} \mathrm{Cr}_{0.1} \mathrm{O}_{4}$ Nanoparticles by Sol-gel Method and Their Applications as an Adsorbent for Water Treatment. Proceeding of The First Conference for Engineering Sciences and Technology (CEST-2018) AIJR Publisher, Garaboulli, Libya, 2018, pp. 756-769.

[26] M. Angelakeris, Z.-A. Li, M. Hilgendorff, K. Simeonidis, D. Sakellari, M. Filippousi, H. Tian, G. Van Tendeloo, M. Spasova, M. Acet, M. Farle, J. Magn. Magn. Mater., 2015, 381, 179-187.

[27] J.Y. Patil, D.Y. Nadargi, J.L. Gurav, I.S. Mulla, S.S. Suryavanshi, Mater. Lett., 2014, 124, 144-147.

[28] P.P. Dorneanu, C. Cojocaru, N. Olaru, P. Samoila, A. Airinei, L. Sacarescu, Appl. Surf. Sci., 2017, 424, 389-396.

[29] C. Cojocaru, P.P. Dorneanu, A. Airinei, N. 
Olaru, P. Samoila, A. Rotaru, J. Taiwan. Ins. Chem. Eng., 2017, 70, 267-281.

[30] H. Wang, Y. Chen, B. Dang, X. Shen, C. Jin, Q. Sun, J. Pei, Carbohydr. Polym., 2018, 196, 117-125.

[31] Y. Ling, J. Yu, B. Lin, X. Zhang, L. Zhao, X. Liu, J. Power Sources., 2011, 196, 2631-2634.

[32] B. Ismail, S.T. Hussain, S. Akram, Chem. Eng. J., 2013, 219, 395-402.

[33] S.I. Ahmad, S.A. Ansari, D.R. Kumar, Mater. Chem. Phys., 2018, 208, 248-257.

[34] F.D. Marques, F.G. Souza Jr, G.E. Oliveira, J. Appl. Polym. Sci., 2016, 133, 43127.

[35] W. Du, G. Dai, B. Wang, Z. Li, L. Li, J. Appl. Polym. Sci., 2018, 135, 46264.

[36] E.G.O. Grance, F.G. Souza Jr., A. Varela, E.D. Pereira, G.E. Oliveira, C.H.M. Rodrigues, J. Appl. Polym. Sci., 2012, 126, E305-E312.

[37] F. Gomes de Souza Jr, J.A. Marins, C.H.M. Rodrigues, J.C. Pinto, Macromol. Mater. Eng., 2010, 295, 942-948.

[38] E. Elias, R. Costa, F. Marques, G. Oliveira, Q. Guo, S. Thomas, F.G. Souza Jr, J. Appl. Polym. Sci., 2015, 132, 41732.

[39] L. Kumar, P. Kumar, M. Kar, J. Alloy. Compd., 2013, 551, 72-81.

[40] V.S. Amrutha, K.S. Anantharaju, D.S. Prasanna, D. Rangappa, K. Shetty, H. Nagabhushana, K. Ashwini, Y.S. Vidya, G.P. Darshan, Arab. J. Chem., 2017, in press. https://doi.org/10.1016/j.arabjc.2017.11.01 6

[41] W. Konicki, D. Sibera, E. Mijowska, Z. Lendzion-Bieluń, U. Narkiewicz, J. Colloid Interface Sci., 2013, 398, 152-160.

[42] A. Deb, M. Kanmani, A. Debnath, K.L. Bhowmik, B. Saha, Desalin. Water. Treat., 2017, 89, 197-209.

[43] W. Wang, Z. Ding, M. Cai, H. Jian, Z. Zeng, F. Li, J.P. Liu, Appl. Surf. Sci., 2015, 346, 348353.

[44] B.K. Wilt, W.T. Welch, J.G. Rankin, Energ. Fuel., 1998, 12, 1008-1012.

[45] S. Kumar, V. Mahto, Chem. Eng. Res. Desing., 2016, 115, 34-43.

[46] V.R. Ognjanovic, G. Aleksic, L. Rajakovic, J.
Hazard. Mater., 2008, 154, 558-563.

[47] L. Yu, G. Hao, Q. Liang, W. Jiang, Ind. Eng. Chem. Res., 2015, 54, 9440-9449.

[48] A.S. Figueiredo, L.P. Icart, F.D. Marques, E.R. Fernandes, L.P. Ferreira, G.E. Oliveira, F.G. Souza, Sci. Total. Environ., 2019, 647, 88-98. [49] Y.C. L'opez, G.A. Ortega, E. Reguera, Colloids. Surf. A, 2019, 561, 120-127.

How to cite this manuscript: Ibrahim A. Amar*, Zohour M. Alshibani, Mabroukah A. AbdulQadir, Ihssin Abdalsamed, Fatima Altohami. Oil Spill Removal from Water by Absorption on Zinc-Doped Cobalt Ferrite Magnetic Nanoparticles. Adv. J. Chem. A, 2019, 2(4), 365-376. 